\title{
The Effect of Er:YAG Laser on Entroccocus faecalis Bacterium in the Pulpectomy of Anterior Primary Teeth
}

\author{
Zahra Bahrololoomi ${ }^{1}$, Farkhondeh Poursina ${ }^{2}$, Reza Birang ${ }^{3}$, Elnaz Foroughi ${ }^{4 *}$, Hazhir Yousefshahi ${ }^{5}$ \\ ${ }^{1}$ Department of Pediatric Dentistry, Faculty of Dentistry, Shahid Sadoughi University of Medical Sciences, Yazd, Iran \\ ${ }^{2}$ Department of Microbiology, School of Medicine, Isfahan University of Medical Sciences, Isfahan, Iran \\ ${ }^{3}$ Periodontology Department, Dental Faculty, Isfahan University of Medical Sciences, Isfahan, Iran \\ ${ }^{4}$ Department of Pediatric Dentistry Faculty of Dentistry, Arak University of Medical Sciences, Arak, Iran \\ ${ }^{5}$ Students Research Center, Dental Faculty, Isfahan University of Medical Sciences, Isfahan, Iran
}

\section{*Correspondence to}

Elnaz Foroughi, Pediatric Dentistry Student, School of Dentistry, Arak University of Medical Sciences, Arak, Iran.

Tel: +989397294591;

Fax: +8632724524

Email: Lnaz_foroughi@yahoo.com

Published online 27 September 2017

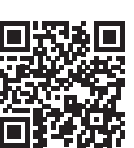

\begin{abstract}
Introduction: Successful root canal therapy depends on the complete elimination of microorganisms such as Entroccocus faecalis, which is impossible to achieve with the traditional methods. Lasers are recently introduced as a new method to solve the problem. The present study is planned and performed to examining the antibacterial effect of Er: YAG laser.

Methods: Sixty extracted anterior primary teeth were prepared and sterilized. E. faecalis bacterium was cultured in canals. Samples were randomly divided into two groups. The first group was disinfected by $\mathrm{NaOCl} 5 / 25 \%$ and $\mathrm{Er}$ : YAG laser and the second group just by $\mathrm{NaOCl} 5 / 25 \%$. Samples of canal contents were cultured and colony counts were calculated. The results were analyzed statistically by SPSS software and Mann Whitney test.

Results: There was no significant difference between colony counts in both groups $(P=0.142)$. But the number of colonies in the first group was lower than in the second group.

Conclusion: Although, Er: YAG laser cannot completely eliminate E. faecalis bacterium, its simultaneous use with $\mathrm{NaOCl}$ decreases $E$. faecalis.

Keywords: Er:YAG; Deciduous; Incisor; Antibacterial; Pulpectomy.
\end{abstract}

\section{Introduction}

Early loss of primary teeth can cause malocclusion, or permanent or temporary cosmetic, speech or functional problems and it is necessary to keep pulp vitality and teeth as much as possible. ${ }^{1}$ Therefore, pulpectomy of primary teeth with irreversible pulpitis or necrotic pulp is necessary, in order to prevent damage to permanent teeth or problems due to early tooth losses. ${ }^{2}$ Successful treatment is directly related to the elimination of microorganism from root canal.2 According to the study by Sjögren et al, the teeth with positive bacterial cultures during canal obturation have a 5-year success rate of about $68 \%$, while teeth with negative culture success rate increases to $94 \% .^{3}$

Among different species of bacteria, Enterococcus faecalis is known as a resistant species to root canal therapy and also as a dominant species in permanent teeth with failed root canal therapy. ${ }^{4-6}$ Moreover, the results of the study by Cogulu et al indicate strong relationship of $E$. faecalis bacterium with periapical radiolucency and pain in primary teeth. ${ }^{7}$ The existence of this bacterium in root canal increases the probability of failure in root canal therapy and also in retreatment. ${ }^{8,9}$ According to another study E. faecalis may remain in the canal after mechanical and chemical preparation of the canal. ${ }^{10}$

Elimination of these resistant types of bacteria from root canals is considered as a serious challenge in root canal therapy. ${ }^{11}$ Recently, some lasers with different wavelengths have proved to be strongly able to clear the canals in permanent and primary teeth. ${ }^{12-15}$ These lasers disinfect the canals from resistant bacteria such as E. faecalis. ${ }^{16-23}$ One of these lasers which are introduced for endodontic treatment is Er:YAG laser. ${ }^{14,15}$ The bactericidal effect of this laser has been showed in some studies. ${ }^{17,18}$ In addition to bactericidal effect, this laser has the minimal thermal damage. ${ }^{23,24}$ In the study by Perin et al on permanent teeth, the effectiveness of Er:YAG laser on E. faecalis was verified. ${ }^{25}$ The study carried out by Noiri et al, just like the former, verified the effectiveness of Er:YAG laser on species of E. faecalis. ${ }^{26}$ The results of the study by Kuvvetli et al on infected primary teeth, showed stronger antibacterial effect of Er:YAG compared with NaOCL

Please cite this article as follows: Bahrololoomi Z, Poursina F, Birang R, Foroughi E, Yousefshahi H. The effect of Er:YAG laser on Entroccocus faecalis bacterium in the pulpectomy of anterior primary teeth. J Lasers Med Sci. 2017;8(4):166-171. doi:10.15171/jlms.2017.30. 
alone. $^{15}$

Regarding the mentioned materials, new methods should be found in order to increase the success rate of root canal therapy in children to prevent damage to permanent teeth. One of these methods is improvement of bacterial elimination, therefore the present study was planned and performed with the aim of examining the effect of Er:YAG laser on E. faecalis in the canals of primary teeth.

\section{Methods}

Teeth Preparation

In this in vitro study, 100 extracted anterior primary teeth were cleaned, disinfected and stored in normal saline. Among them, 60 teeth which were resorbed less than 1/4 of the root were chosen. Dental crowns were removed by diamond fissure bur (Tees Kavan, Iran) to obtain uniform teeth with a root length of $10 \mathrm{~mm}$. Then, the roots were prepared and shaped with $9 \mathrm{~mm}$ working length with K-files up to \#50 (Mani, Japan). During the process of preparing and shaping, canals were rinsed with $\mathrm{NaOCl}$ 5/25\% (Merck, Germany). After preparation, canals were treated with $17 \%$ EDTA (Asia-Shimi-Teb, Iran) for 5 minutes to remove the smear layer. Then the canals were irrigated with normal saline and then the teeth were put into the autoclave with a temperature of $121^{\circ} \mathrm{C}$ for 30 minutes.

\section{Root Canal Contamination}

Pure E. faecalis (ATCC 19212) were cultivated in brain heart infusion (BHI, HI Media, Mumbai, India) broth medium and then suspended in $4.0 \mathrm{~mL}$ of brain heart infusion. The cell suspension was adjusted to match the turbidity of E. Faecalis at $1.5 \times 10^{8}$ colony forming units (CFU)/mL (equivalent t0 $\sim 0.5 \mathrm{McFarland}$ standards). The end of each root was sealed with temporary cement (Cimpat, Septodont, Saint - Maur-Des- fosses, France) and $4 \mu \mathrm{L}$ of the suspension was placed into the root canal using an automatic pipette. The specimens were placed into petri dishes covered with wet gauze and incubated for 48 hours at $37^{\circ} \mathrm{C}$. Then teeth were cleaned by K-files up to \#60 and rinsed with $\mathrm{NaOCl} \mathrm{5/25 \% .}$

\section{Laser Radiation}

The samples were randomly divided into 2 equal groups according to randomized number table; each group contained 30 teeth. The first group was exposed to laser radiation and the second one was not. Er:YAG laser (Er:YAG Fidelis Plus, Fotona, Slovenia) ( $2940 \mathrm{~nm}$, fiber with $20 \mathrm{~mm}$ length and 300 micron diagonal) was applied. The laser with a power of $1 \mathrm{~W}$, energy of $100 \mathrm{~mJ}$, $10 \mathrm{~Hz}$ frequency, power density of $1414.71 \mathrm{~W} / \mathrm{cm}^{2}$, energy density of $141.471 \mathrm{~J} / \mathrm{cm}^{2}$ was used spirally in short pulse mode $(250 \mu$ s) for 20 seconds (over 2 spans of 10 seconds and with the interval of 2 seconds). Laser irradiation started from the coronal part that was $10 \mathrm{~mm}$ away from radiographic apex and $9 \mathrm{~mm}$ away from end point of preparation process.

Sampling and Examining the Samples

The canals were dried with sterile paper point, and then dentinal chips were produced in each tooth by sterile Gates Gliden \#3 (Maillefer, Ballaigues, Switzerland). After that, the chips of dentin were taken from the inside of canals with a moisturized paper point which was moisturized with distilled water, and were transferred into the culture environment BHI about $1 \mathrm{~mL}$. The samples were shaken, and about $1 \mu \mathrm{L}$ of each sample was cultured in the solid culture environment of blood agar. After 24 hours' incubation in $37^{\circ} \mathrm{C}$, the colonies were counted. Three teeth were chosen randomly as control. These teeth, after 48 hours' incubation, were dried with a paper point, and a dentine sample was taken from them. In a similar manner, the bacteria in dentinal tubules of other samples were counted. The results were analyzed statistically by SPSS software version 21 with Mann-Whitney test.

\section{Results}

Mean count of bacterial colonies for the 2 groups is presented in Table 1. According to Mann-Whitney test results, there was no significant difference between the groups ( $P$ value $>0.05)$.

Despite the absence of any significant relation, the mean colonies count in the first group (Figure 1) was lower than the second group (Figure 2). The mean colonies count was $2.4 \pm 1.42$ for first group and $5.9 \pm 16.88$ for Second group. According to the results, 15 samples in the first group and 12 samples in the second group were completely free of bacterial colonies (Figure 3).

Table 1. Mean Bacterial Colonies

\begin{tabular}{lcc}
\hline & Mean Colonies Count & Colonies Free Samples Count \\
\hline Group 1 & $2.4 \pm 1.42$ & 15 \\
Group 2 & $5.9 \pm 16.88$ & 12 \\
\hline
\end{tabular}

Group 1: Hypochlorite sodium and laser irradiation.

Group 2: Hypochlorite sodium.

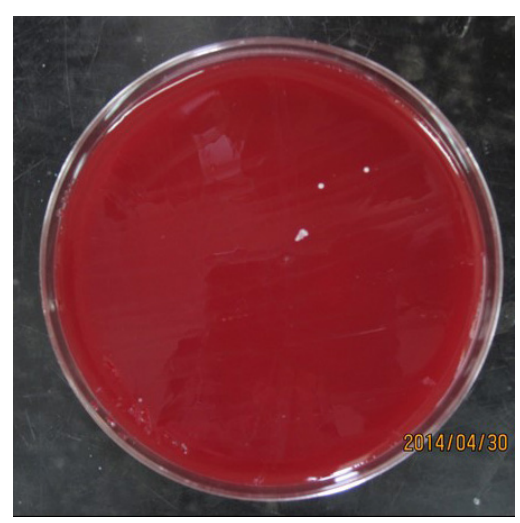

Figure 1. A Sample of Colony Count in First Group. 


\section{Discussion}

The success of pulpectomy in children is directly related to the elimination rate of micro-organisms from root canals. $^{2}$ On the other hand, complete elimination of micro-organisms after cleaning, shaping and rinsing with conventional methods, is not possible in all cases. ${ }^{24,25}$ As the results of the studies carried out by Kouchi et al show, bacteria can penetrate into dentinal tubules to a depth of $1100 \mu \mathrm{m},{ }^{27}$ while according to another study, chemical substances can penetrate into a depth of $130 \mu \mathrm{m}$ at most. ${ }^{28}$ Among different bacteria existing in infected pulp tissue, E. faecalis (facultative anaerobic gram positive cocci) is a common endodontic pathogen in teeth with failure in pulpectomy. ${ }^{7,28-30}$ The results of the study by Cogulu et al show that $E$. faecalis is strongly related to periapical radiolucency and pain in primary and permanent teeth.? Therefore, elimination of bacteria such as E. faecalis from the root canal is considered as a challenge in pulpectomy of primary and permanent teeth. ${ }^{31}$

In order to solve this problem, laser has been introduced recently for disinfecting root canals. ${ }^{32-34}$ Lasers are of different kinds and their application may lead to different results. The results of the work by Moritz et al show that performance of diode and Nd:YAG lasers for eliminating $E$. faecalis in pulpectomy, was better than Er:YAG laser. It is noteworthy that the results of applying diode and Nd:YAG laser were similar to the results of using $\mathrm{NaOCl} .^{21,35}$ Different studies showed conflicting results when comparing chemical cleaning methods with laser. For instance, the results of the study by Kuştarci showed that NaOCL $5.25 \%$ had better effect than KTP laser. ${ }^{36}$ The results of the study by Eldeniz et al showed that NaOCL $5.25 \%$ had better effect than Er:Cr:YSGG laser on the elimination of $E$. faecalis from infected root canal. ${ }^{37}$ However, the results of another study showed that applying Diode laser in comparison with mechanical and chemical methods, causes more elimination of E. faecalis in the apical part of root canals. ${ }^{38}$ In the study by Kuvvetli et al, the effects of Er:YAG laser in molar primary teeth was similar to the effects of NaOCL $1.25 \%{ }^{15}$ Therefore, it seems lasers can be effective in root canal disinfection. Moreover, more studies on applying laser for primary teeth is necessary because most of the previous studies on laser are carried out on permanent teeth and structural differences between permanent and primary teeth affect the results. ${ }^{39,40}$

Er:YAG laser transmits energy through photo ablation process. Hydroxyapatite absorbs maximum energy at $2900 \mathrm{~nm}$ which is close to Er:YAG laser wavelength. The performance of this laser in preparing tooth cavity is approved in many studies. ${ }^{41-45}$ According to the results of the study by Moritz et al on the antibacterial effects of some lasers such as Er:YAG, Nd:YAG and Ho:YAG, it can be concluded that Er:YAG laser is more effective than the others. ${ }^{21,35}$ These results are also seen in the study by Schoop et al that show Er:YAG laser in comparison

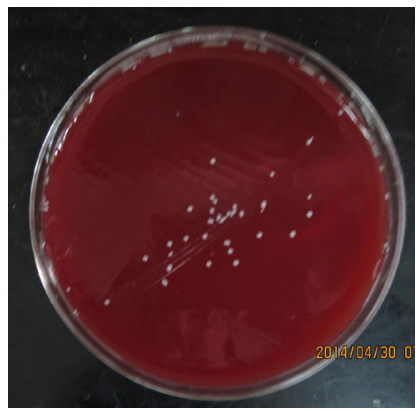

Figure 2. A Sample of Colony Count in Second Group.

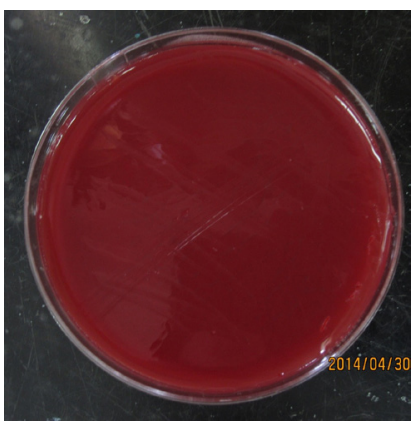

Figure 3. A Sample of Colonies Free Medium.

with Nd:YAG, diode and Er:Cr:YSGG in power of $1 \mathrm{~W}$, has been the best at limiting the growth of E. faecalis in permanent teeth. ${ }^{12}$ On the contrary, the results of the study by Kuvvetli et al on molar primary teeth show that antibacterial effects of Doide laser have been better than those of Er:YAG laser. ${ }^{15}$ Generally, it seems that Er:YAG laser is an efficient laser for disinfecting the root canal. According to the results of the present study, Er:YAG laser also decreases the E. faecalis in anterior primary teeth. This result was approved in the study by Kuvvetli et al on molar primary teeth. ${ }^{15}$

Laser has changeable parameters, so different results can be gained. ${ }^{46-48}$ Power is one of those parameters. According to the study by Takeda et al the power of $1 / 2 \mathrm{~W}$ is adequate for clearing the smear layer, ${ }^{11,49,50}$ moreover, the power of $1 / 2 \mathrm{~W}$ is adequate for disinfecting the canal. ${ }^{51}$ Accordingly, in the present study, because the primary teeth are chosen and there is structural difference between primary and permanent teeth, the least power $(1 \mathrm{~W})$ used in other studies is chosen and examined. According to the results of the study by Schoop et al, a power of $1 \mathrm{~W}$ can only decrease the bacteria but a power of $1.5 \mathrm{~W}$ is adequate for complete elimination of E. Faecalis. ${ }^{12}$ The results of the present study also show that a power of $1 \mathrm{~W}$ does not completely eliminate $E$. faecalis bacterium from the canal. According to the mentioned items, it appears that complete elimination of the bacteria from the root canal needs increased powers. It is noteworthy that increasing the power of the laser causes danger of increase in temperature and damage to 
periodontal tissues. But it should be considered that due to higher absorption of Er:YAG laser's energy by water in comparison with other lasers such as Nd:YAG and $\mathrm{CO}_{2}$, the possibility of increasing temperature is minimum. ${ }^{48}$ Water or air sprays are some of the efficient factors in preventing thermal damage. ${ }^{49-51}$ The study by Theodoro et al showed that applying laser for 30 seconds with water spray can decrease temperature $\left(-2.2 \pm 2.5^{\circ} \mathrm{C}\right) .{ }^{52}$ It should be taken into consideration that using too much water or air cooling results in energy absorption and decreased ablation effect of laser. ${ }^{53}$

Another parameter that affects the antibacterial effect of laser, is radiation time. The results of the study by Kuvvetli et al showed that applying laser for 45 seconds causes a decrease in E. faecalis in the root canal of primary molar teeth. ${ }^{15}$ The results of the present study also indicate that the number of colonies in the canal of anterior primary teeth decreased by applying laser for 20 seconds. It should be mentioned that different studies on radiation time on antibacterial properties indicate different effects of radiation time. In the study by Kuvvetli et al, increasing time improves the antibacterial effect of Er:YAG laser. ${ }^{15}$ While, according to the results of another study, increasing the time of laser application would not improve the cleaning effect. ${ }^{54}$ Therefore, more studies on laser radiation time are necessary.

Another factor is energy. According to the results of the study by Noiri et al on the effects of Er:YAG laser on E. faecalis, increasing laser energy rate decreases the bacterial count, accordingly $20 \mathrm{~mJ}$ energy does not make any change in bacterial growth while 40 and $80 \mathrm{~mJ}$ decrease bacterial population. ${ }^{26}$ In the present study also, $100 \mathrm{~mJ}$ energy could not eliminate E. faecalis bacterium completely from root canal of primary teeth. Therefore, regarding the role of this bacterium in the pulpectomy failure, more studies are advised.

It should be considered that the proper amount of energy for elimination of different species of bacteria may be different, for example according to the results of the study by Noiri et al on the effects of Er:YAG laser, the amount of energy that is adequate for complete elimination of gram negative species, can only decrease the growth of gram positive species. ${ }^{26}$ Therefore, despite the fact that $100 \mathrm{~mJ}$ energy is not adequate for complete elimination of $E$. faecalis from the root canal, it is possible that regarding the multi-bacterium nature of pulp disease, ${ }^{7,55}$ this laser with the investigated parameters is suitable for disinfection of root canal from other bacteria.

In addition to mechanical methods and new tools such as laser, chemical materials such as $\mathrm{NaOCl}$ are used for disinfecting the canal. It is noteworthy that the efficiency of $\mathrm{NaOCl}$ in root canal disinfection depends on the of $\mathrm{NaOCl}$ concentration. ${ }^{60-62}$ According to the study by Gomes et al the most effective concentration of $\mathrm{NaOCI}$ for E. faecalis elimination, is 5.25\%. ${ }^{60}$ Accordingly, a concentration of $5.25 \%$ is used in the present study. In the present study, the group which was disinfected only by $\mathrm{NaOCl} 5.25 \%$ showed decrease in the number of $E$. faecalis. Regarding the fact that E. faecalis in comparison with other species such as Actinomyces naeslundii and Candida albicans is more resistant to $\mathrm{NaOCl},{ }^{61}$ therefore, choosing an appropriate concentration of $\mathrm{NaOCl}$ is very important. $\mathrm{NaOCl}$ with different concentrations lead to contradictory results. For instance, in the study by Spratt et al, using $\mathrm{NaOCl} 3 \%$ resulted in complete elimination of E. faecalis ${ }^{63}$ which is contrary to the results of the present study.

\section{Conclusion}

According to the results, laser application alongside conventional methods do not significantly improve elimination of E. faecalis from root canal of primary teeth. However, regarding to the effect of different parameters on the antibacterial effect of laser, more studies on power and radiation time of laser is necessary. Moreover, clinical studies to verify these results are also necessary.

\section{Ethical Consideration}

The proposal of study was approved by the Ethics committee, Faculty of Dentistry, Shahid Sadoughi University of Medical Sciences (\#32085).

\section{Conflict of Interests}

The authors declare that there is no conflict of interest.

\section{References}

1. Fuks A, Kupietzki A. Pulp therapy for the primary dentition. In: Casamassimo PS FH, McTigue DJ, Nowak AJ, eds. Pediatric Dentistry Infancy Through Adolescence. 5th ed. St. Louis, Missouri: Elsvier Saunders; 2013.

2. Cordeiro MM, Rocha MJ. The effects of periradicular inflamation and infection on a primary tooth and permanent successor. J Clin Pediatr Dent. 2005;29(3):193200.

3. Sjögren U, Figdor D, Persson S, Sundqvist G. Influence of infection at the time of root filling on the outcome of endodontic treatment of teeth with apical periodontitis. Int Endod J. 1997;30(5):297-306.

4. Dederich DN, Zakariasen KL, Tulip J. Scanning electron microscopic analysis of canal wall dentin following neodymium-yttrium-aluminum-garnet laser irradiation. $J \quad$ Endod. 1984;10(9):428-431. doi:10.1016/s00992399(84)80264-2.

5. Kantola S, Laine E, Tarna T. Laser-induced effects on tooth structure. VI. X-ray diffraction study of dental enamel exposed to a CO2 laser. Acta Odontol Scand. 1973;31(6):369-379.

6. Miserendino LJ. The laser apicoectomy: endodontic application of the CO2 laser for periapical surgery. Oral Surg Oral Med Oral Pathol. 1988;66(5):615-619.

7. Cogulu D, Uzel A, Oncag O, Eronat C. PCR-based identification of selected pathogens associated with endodontic infections in deciduous and permanent teeth. Oral Surg Oral Med Oral Pathol Oral Radiol Endod. 2008;106(3):443-449. doi:10.1016/j.tripleo.2008.03.004. 
8. Engstrom B. Correlation of positive culture with the prognosis for root canal treatment. Odontol Revy. $1964 ; 15: 257-270$

9. Sundqvist G, Figdor D, Persson S, Sjogren U. Microbiologic analysis of teeth with failed endodontic treatment and the outcome of conservative re-treatment. Oral Surg Oral Med Oral Pathol Oral Radiol Endod. 1998;85(1):86-93.

10. Gomes BP, Lilley JD, Drucker DB. Variations in the susceptibilities of components of the endodontic microflora to biomechanical procedures. Int Endod J. 1996;29(4):235241.

11. Takeda FH, Harashima T, Kimura Y, Matsumoto $\mathrm{K}$. Efficacy of Er:YAG laser irradiation in removing debris and smear layer on root canal walls. J Endod. 1998;24(8):548551. doi:10.1016/s0099-2399(98)80075-7.

12. Schoop U, Kluger W, Moritz A, Nedjelik N, Georgopoulos A, Sperr W. Bactericidal effect of different laser systems in the deep layers of dentin. Lasers Surg Med. 2004;35(2):111116. doi:10.1002/lsm.20026.

13. Matsuoka E, Jayawardena JA, Matsumoto K. Morphological study of the Er,Cr:YSGG laser for root canal preparation in mandibular incisors with curved root canals. Photomed Laser Surg. 2005;23(5):480-484. doi:10.1089/ pho.2005.23.480

14. Schoop U, Kluger W, Dervisbegovic S, et al. Innovative wavelengths in endodontic treatment. Lasers Surg Med. 2006;38(6):624-630. doi:10.1002/lsm.20331.

15. Kuvvetli SS, Sandalli N, Topcuoglu N, Kulekci G. Antibacterial efficacy of diode and Er: YAG laser irradiation in experimentally contaminated primary molar root canals. J Clin Pediatr Dent. 2009;34(1):43-8.

16. Varella $\mathrm{CH}$, Pileggi R. Obturation of root canal system treated by Cr, Er: YSGG laser irradiation. I Endod. 2007;33(9):1091-1093. doi:10.1016/j.joen.2007.05.012.

17. Kivanc BH, Ulusoy OI, Gorgul G. Effects of Er:YAG laser and Nd:YAG laser treatment on the root canal dentin of human teeth: a SEM study. Lasers Med Sci. 2008;23(3):247252. doi:10.1007/s10103-007-0474-6.

18. Mehl A, Folwaczny M, Haffner C, Hickel R. Bactericidal effects of $2.94 \mu \mathrm{m}$ Er:YAG-laser radiation in dental root canals. J Endod. 1999;25(7):490-493. doi:10.1016/S00992399(99)80288-X.

19. Dostálová $\mathrm{T}$, Jelínková $\mathrm{H}$, Houšová $\mathrm{D}$, et al. Endodontic treatment with application of Er:YAG laser waveguide radiation disinfection. J Clin Laser Med Surg. 2002;20(3):135-139. doi:10.1089/104454702760090218.

20. Jelinkova H, Dostalova T, Duskova J, et al. Er:YAG and alexandrite laser radiation propagation in root canal and its effect on bacteria. J Clin Laser Med Surg. 1999;17(6):267272.

21. Moritz A, Schoop U, Goharkhay K, et al. The bactericidal effect of Nd:YAG, Ho:YAG, and Er:YAG laser irradiation in the root canal: an in vitro comparison. J Clin Laser Med Surg. 1999;17(4):161-164. doi:10.1089/clm.1999.17.161.

22. Schoop U, Moritz A, Kluger W, et al. The Er:YAG laser in endodontics: results of an in vitro study. Lasers Surg Med. 2002;30(5):360-364. doi:10.1002/lsm.10054.

23. Boj JR, Poirier C, Espasa E, Hernandez M, Espanya A. Lower lip mucocele treated with an erbium laser. Pediatr Dent. 2009;31(3):249-252.

24. Boj JR, Poirier C, Hernandez M, Espasa E. Laser-assisted treatment of a dentigerous cyst: case report. Pediatr Dent. 2007;29(6):521-524.
25. Perin FM, Franca SC, Silva-Sousa YT, et al. Evaluation of the antimicrobial effect of Er:YAG laser irradiation versus $1 \%$ sodium hypochlorite irrigation for root canal disinfection. Aust Endod J. 2004;30(1):20-22.

26. Noiri Y, Katsumoto T, Azakami H, Ebisu S. Effects of Er:YAG laser irradiation on biofilm-forming bacteria associated with endodontic pathogens in vitro. J Endod. 2008;34(7):826-829. doi:10.1016/j.joen.2008.04.010.

27. Kouchi Y, Ninomiya J, Yasuda H, Fukui K, Moriyama T, Okamoto H. Location of Streptococcus mutans in the dentinal tubules of open infected root canals. J Dent Res. 1980;59(12):2038-2046.

28. Berutti E, Marini R, Angeretti A. Penetration ability of different irrigants into dentinal tubules. J Endod. 1997;23(12):725-7.

29. Byström A, Sundqvist G. Bacteriologic evaluation of the effect of 0.5 percent sodium hypochlorite in endodontic therapy. Oral Surg Oral Med Oral Pathol. 1983;55(3):30712.

30. Byström A, Sunvqvist G. The antibacterial action of sodium hypochlorite and EDTA in 60 cases of endodontic therapy. Int Endod J. 1985;18(1):35-40.

31. Hancock HH 3rd, Sigurdsson A, Trope M, Moiseiwitsch J. Bacteria isolated after unsuccessful endodontic treatment in a North American population. Oral Surg Oral Med Oral Pathol Oral Radiol Endod. 2001;91(5):579-586. doi:10.1067/ moe.2001.113587.

32. Molander A, Reit C, Dahlen G, Kvist T. Microbiological status of root-filled teeth with apical periodontitis. Int Endod J. 1998;31(1):1-7.

33. Portenier I, Waltimo TMT, Haapasalo M. Enterococcus faecalis- the root canal survivor and 'star' in post-treatment disease. Endod Topics. 2003;6(1):135-59. doi:10.1111/ j.1601-1546.2003.00040.x.

34. Harashima T, Takeda FH, Zhang C, Kimura Y, Matsumoto $\mathrm{K}$. Effect of argon laser irradiation on instrumented root canal walls. Endod Dent Traumatol. 1998;14(1):26-30.

35. Moritz A, Gutknecht N, Schoop U, Goharkhay K, Doertbudak O, Sperr W. Irradiation of infected root canals with a diode laser in vivo: results of microbiological examinations. Lasers Surg Med. 1997;21(3):221-226.

36. Kuştarci A, Sümer Z, Altunbaş D, Koşum S. Bactericidal effect of KTP laser irradiation against Enterococcus faecalis compared with gaseous ozone: an ex vivo study. Oral Surg Oral Med Oral Pathol Oral Radiol Endodontol. 2009;107(5):e73-e9.

37. Eldeniz A, Ozer F, Hadimli H, Erganis O. Bactericidal efficacy of Er, Cr: YSGG laser irradiation against Enterococcus faecalis compared with $\mathrm{NaOCl}$ irrigation: an ex vivo pilot study. Int Endod J. 2007;40(2):112-119.

38. Pashley D, Michelich V, Kehl T. Dentin permeability: effects of smear layer removal. J Prosth Dent. 1981;46(5):531-7.

39. Önal B, Ertl T, Siebert G, Müller G. Preliminary report on the application of pulsed $\mathrm{CO}_{2}$ laser radiation on root canals with $\mathrm{AgCl}$ fibers: A scanning and transmission electron microscopic study. J Endod. 1993;19(6):272-6.

40. Preethee T, Kandaswamy D, Arathi G, Hannah R. Bactericidal effect of the $908 \mathrm{~nm}$ diode laser on Enterococcus faecalis in infected root canals. J Conserv Dent. 2012;15(1):46-50. doi:10.4103/0972-0707.92606.

41. Hirayama A, Yamada M, Miake K. [An electron microscopy study on dentinal tubules of human deciduous teeth]. Shikwa Gakuho. 1986;86(6):1021-1031. 
42. Sumikawa DA, Marshall GW, Gee L, Marshall SJ. Microstructure of primary tooth dentin. Pediatr Dent. 1999;21(7):439-444.

43. Hibst R. Lasereinsatz in der Zahnmedizin. Med Tech. 1991;4:18-23.

44. Hibst R, Keller U. Experimental studies of the application of the Er:YAG laser on dental hard substances: I. Measurement of the ablation rate. Lasers Surg Med. 1989;9(4):338-344.

45. Keller U, Hibst R. [Ablative effect of an Er:YAG laser on enamel and dentin]. Dtsch Zahnarztl Z. 1989;44(8):600602.

46. Keller U, Hibst R. Wirkungsweise und Indikationen des Er: YAG lasers in der Zahn-Mund-und Kieferheilkunde. Magazin für ZMK. 1992;4:6-10.

47. Keller U, Raab WH, Hibst R. [Pulp reactions during Erbium YAG laser irradiation of hard tooth structure]. Dtsch Zahnarztl Z. 1991;46(2):158-60.

48. Goya C, Yamazaki R, Tomita Y, Kimura Y, Matsumoto K. Effects of pulsed Nd:YAG laser irradiation on smear layer at the apical stop and apical leakage after obturation. Int Endod J. 2000;33(3):266-271.

49. Takeda FH, Harashima T, Eto JN, Kimura Y, Matsumoto K. Effect of Er:YAG laser treatment on the root canal walls of human teeth: an SEM study. Endod Dent Traumatol. 1998;14(6):270-273

50. Takeda FH, Harashima T, Kimura Y, Matsumoto K. Comparative study about the removal of smear layer by three types of laser devices. J Clin Laser Med Surg. 1998;16(2):117-122. doi:10.1089/clm.1998.16.117.

51. Cecchini SCM, Zezell DM, Bachmann L, Pinotti M, Nogueira GEC, Eduardo CdP. Thermal effects during in vitro intracanal application of Er: YAG laser. Program \& Abstracts: International Society for Lasers in Dentistry; 1998.

52. Theodoro LH, Haypek P, Bachmann L, et al. Effect of Er: YAG and diode laser irradiation on the root surface: morphological and thermal analysis. $J$ Periodontol. 2003;74(6):838-843.

53. Akimoto N, Momoi Y, Kohno A, et al. Histologic observation of direct capped pulps with LinerBond-2 adhesive system. J Dent Res. 1997.

54. Levy G. Cleaning and shaping the root canal with a Nd:YAG laser beam: a comparative study. J Endod. 1992;18(3):123127. doi:10.1016/s0099-2399(06)81312-9.

55. Takeda FH, Harashima T, Kimura Y, Matsumoto K. A comparative study of the removal of smear layer by three endodontic irrigants and two types of laser. Int Endod J. 1999;32(1):32-39.

56. Keller U, Hibst R. Experimental studies of the application of the Er: YAG laser on dental hard substances: II. Light microscopic and SEM investigations. Lasers Surg Med. 1989;9(4):345-51.

57. Lee BS, Jeng JH, Lin CP, Shoji S, Lan WH. Thermal effect and morphological changes induced by Er:YAG laser with two kinds of fiber tips to enlarge the root canals. Photomed Laser Surg. 2004;22(3):191-197. doi:10.1089/1549541041438704.

58. Soares F, Varella CH, Pileggi R, Adewumi A, Guelmann M. Impact of Er,Cr:YSGG laser therapy on the cleanliness of the root canal walls of primary teeth. J Endod. 2008;34(4):474477. doi:10.1016/j.joen.2008.02.006.

59. Siqueira JF. Tratamento das infecções endodônticas. São Paulo: Medsi; 1997.

60. Gomes BP, Ferraz CC, Vianna ME, Berber VB, Teixeira FB, Souza-Filho FJ. In vitro antimicrobial activity of several concentrations of sodium hypochlorite and chlorhexidine gluconate in the elimination of Enterococcus faecalis. Int Endod J. 2001;34(6):424-428.

61. Radcliffe CE, Potouridou L, Qureshi R, et al. Antimicrobial activity of varying concentrations of sodium hypochlorite on the endodontic microorganisms Actinomyces israelii, A. naeslundii, Candida albicans and Enterococcus faecalis. Int Endod J. 2004;37(7):438-446. doi:10.1111/j.13652591.2004.00752.x.

62. Siqueira JF Jr, Rocas IN, Favieri A, Lima KC. Chemomechanical reduction of the bacterial population in the root canal after instrumentation and irrigation with $1 \%, 2.5 \%$, and $5.25 \%$ sodium hypochlorite. J Endod. 2000;26(6):331-334. doi:10.1097/00004770-20000600000006.

63. Spratt DA, Pratten J, Wilson M, Gulabivala K. An in vitro evaluation of the antimicrobial efficacy of irrigants on biofilms of root canal isolates. Int Endod J. 2001;34(4):300307. 